\title{
Development of Literary Education with Cultural Wisdom of Classical Stories
}

\author{
Abdurahman ${ }^{1, *}$ Elya Ratna $^{1}$ Zulfikarni $^{1}$ Ngusman $^{1}$ \\ ${ }^{1}$ Indonesian Language Department, Universitas Negeri Padang, Padang, Indonesia \\ *Corresponding author. Email: abdurahman.padang@gmail.com
}

\begin{abstract}
This paper aims to explain cultural wisdom in classic regional stories in Indonesia which is proposed as the development of literary education. The research problem begins with the phenomenon of school graduates whose knowledge competence is adequate but weak in cultural wisdom. This is a problem that is thought to occur because literary learning is not oriented to character values, especially cultural values that are people's expectations to live together. Although school graduates are expected to have a good culture, it turns out that there are still many of them who are not culturally aware so that they do not strengthen the culture of their community. To improve this dilemma, the study of classical stories and the findings of the cultural wisdom contained in them can be taken into consideration in the development of literary education. In a research study on cultural wisdom in classical stories, it was found that there are five messages of cultural wisdom that become hope in developing life that need to be associated with character values, namely about cultural wisdom, the nature of life, and the nature of life. work, the nature of time, the nature of relationships with others, and the nature of life. relationship with the environment. The message of cultural wisdom is considered very relevant in literary education for modern life, which is not only oriented to globalization but also people who strongly adhere to local cultural values that are superior in life. This paper also aims to explain the need for messages of cultural wisdom in classical stories as materials for developing literary education so that it becomes an education based on the nation's noble cultural values.
\end{abstract}

Keywords: cultural wisdom, classic stories, literary education.

\section{INTRODUCTION}

Since the reform era in Indonesia until the beginning of the 2020 pandemic, many education observers have given their opinions and reviewed their thoughts on inequality in the implementation and management of education. Among them, Suyatno stated that national education is still ongoing with magical awareness and nave awareness, and has not yet developed critical awareness [1]. Furthermore, Taufik an entrepreneur stated that our education is too directed at mastering theories and concepts and pays less attention to soft competencies to stimulate initiative, creativity, and innovation [2]. Likewise, Muslich states that the world of education has lost the noble values of humanity because it is subject to the market and not enlightenment to students [3]. In addition, Abdurahman sees literary education as experiencing inequality due to the imbalance in mastery of science with literature that teaches morals related to the meaning of life [4].
The depiction of educational inequality is increasingly being questioned because there are many abuses of rules and cultural crises in people's lives because literature does not play a role [5]. People who are involved as perpetrators of cultural deviation are not only people with low education but also people with high education. They are involved with various social deviations that are contrary to the noble values of culture and religion. This phenomenon is a question for education observers, what is actually lacking in education so far? Why do those who have tasted education still commit crimes and why are they further and further away from the good culture that society expects? The existence of this phenomenon is assumed to be closely related to the implications of educational outcomes for social life. Rivai states that various community problems are conditions that show the irrelevant implementation of education with educational goals that exist in the educational goals themselves [6]. 
The condition of the people is as described by ElShirazy, an Indonesian author, in his novel "Api Tauhid": "They are people who are weak in faith so they are easily thrown out of good culture" [7]. The slander of the culture of life grabbed them day and night. The hungry wolves of culture were ready to tear them apart. Spiritual ignorance is rampant and ironically they claim to be all-knowing. Disobedience creeps everywhere into tantalizing propaganda. People are beset by endless anxiety, fear, and uncertainty. This fact reminds us of the word of Allah, "Their example is that of those who light a fire, so after the fire illuminates all around them Allah removes the light (which shines) on them, and leaves them in darkness, unable to see (Quran, 2:17). [8]. This situation is certainly in accordance with the opinion of Lickona which states that a nation is headed for destruction when violence increases, bad language use, increases self-destructive behavior, blurred moral guidelines, decreased work ethic, disrespect for elders, low sense of responsibility, dishonesty, and mutual suspicion and hatred. If you look closely, all of this is increasing and worrying [9].

On the other hand, to achieve good educational outcomes in Indonesia, reforms in educational programs do not stop. The curriculum continues to be developed and now the school has implemented the 2013 curriculum instead of the 2006 curriculum. In 2010 it was also announced the need for literature education and since then literary education has been implemented in schools. Now in 2021 a new curriculum is designed with three characteristics: competency-based, flexible, and Pancasila character [10]. For this reason, the quality of teachers has been improved through training programs and now the training of driving teachers with better insight than before. In addition, along with curriculum renewal, learning approaches are also developing, the assessment system is getting better and there are more and more learning media.

Apart from the real impact of implementing the 2013 curriculum, the results of literary education achieved today are not yet above the target quality, especially when compared to other countries. Graduates who have graduated have not shown attitudes and creativity that are more like the cultural character expected by society. The complexity of the phenomena that occur in society indicates that the field of education always requires various materials for development that allow for renewal that can improve the condition of society. For this reason, contributions from various fields of educational enrichment need to be clearly made by various parties, such as philosophical educational innovation, pradigmatic renewal, socio-political innovation, and technological renewal [11]. All of that, for educational outcomes that are expected by the community to be satisfactory for an honest and comfortable life.

Responding to the educational dilemma, it is necessary to enrich education that comes from cultural wisdom that lives in the cultural traditions of the community. In this case, the author has suggested to revisit and open the cultural messages that exist in society, especially those in folklore [12]. One of them that needs to be considered is the message of cultural wisdom contained in classical folklore. There are messages in the folklore that describe expectations for the results of their education in life and life [13]. It's just that the educational outcomes they expect in their culture have not been stated explicitly or not conveyed clearly. For that, an explanation of it, needs to be described in scientific writing.

If so far educational innovation has been associated with new discoveries, it has not yet met the community's need for morals, so now we need to re-open our own cultural message for educational renewal. Abdurahman in a study with the theme of educational cultural wisdom found five general messages in folklore that could be contributed as innovation materials in literary education [14]. The five messages are in the form of a thesis about humans with the nature of life, the nature of work, the nature of social relations, the nature of time, and the nature of the relationship with nature. The five messages are sourced from ten titles of Minangkabau folklore which the author analyzes with semiotic studies. The message is an idealized hope by the cultural community that supports folklore to be actualized in education and life.

Cultural messages from folklore are statements of relevant cultural messages that are contributed to obtain educational outcomes for people's lives based on their own culture. The development of education based on the contribution of cultural messages is expected to open cultural insight about the importance of culture-based education. It is also related to the need for school graduates armed with the application of character values from their own culture. On the one hand, our education must be built with the results of new discoveries in the field of science and technology, but on the other hand we want the nation's children not to lose their identity and good character that has been idealized in their culture. Both, of course, are very important for the progress of the nation. 


\section{METHOD}

This study uses a qualitative research type, which is a research method used to examine cultural wisdom in the condition of natural classical story objects, in which the researcher is the key instrument. This study emphasizes the message of cultural wisdom in classical stories. The approach of this research is content analysis. Content analysis of folklore is a study of words, sentences, meaning of usage, and interpretation [16]. Meanwhile, judging from the data presentation technique, this study uses a descriptive pattern. The purpose of the descriptive pattern is a research method that seeks to describe and interpret objects according to what they are. The descriptive pattern produces an interpretation of the description of the message of cultural wisdom in the classic story [17]. The data and sources of data in this study are ten folk tales from the Minangkaba region, Sumatra, Indonesia.

\section{RESULT AND DISCUSSION}

\subsection{Messages of Cultural Wisdom in Classical Stories}

In this section, the understanding of cultural wisdom in classical Minangkabau folklore and forms of cultural wisdom is discussed. First, the concept of wisdom is a noun which means 'wisdom or intelligence' [18]. Wisdom can be in the form of words or actions, actions that show the nature of wisdom, namely wise, clever and clever, and knowledgeable. Rahyono states that wisdom is the intelligence possessed by a group of (ethnic) humans obtained through their life experiences and manifested in their cultural characteristics [19]. When related to this research, wisdom means intelligence and wisdom produced by cultural communities that are recorded or documented in folklore based on the life experiences they have gone through. In connection with that definition, what is meant by cultural wisdom messages are good advice, instructions, warnings, and reprimands that are carried out by someone in the form of norms, rules, and actions that show intelligence and wisdom [14].

Second, in the research that the author has carried out, classic stories that are used as research sources already exist in society as a means of educating the values of life. Stories survive because the values they contain can provide guidance to the community in life. The research findings show that the story invites the reader to believe that life is God's destiny and in living life the best attitude is to fear Him. Stories also give messages about the importance of knowledge and mastery of the material. By inviting people to believe in Allah, the hedonic life turns into a life of surrender, worship, and struggle in the way of Allah. With science, it is illustrated that the change of a stupid character becomes an educated person and has the potential to become a leader and position. Then, with sufficient wealth and material, the character of the story is free from poverty to become a rich person who has many benefits in helping the life of his family and society. More than that, the ethical values in the story direct the characters to become people who have personalities in life together. The story suggests that the reader must have faith, knowledge, ethics, and wealth and is useful in life as a person with a complete personality. Thus, the cultural values of stories based on religion, science, ethics, and mastery of the material need to be considered in shaping future educational reforms, especially in shaping the character of society.

Third, the authors present messages of cultural wisdom in the form of general statements about educational cultural wisdom from Minangkabau folklore which are research findings:

Cultural wisdom in the nature of life, including the following:

1) The character of the story believes that life is believed to be the destiny of God Almighty, and life is believed not only in this world but there is still an afterlife. 2) In living the life of the story, the character is pious and worships Allah in order to be safe in this world and the hereafter. 3) In living life, the characters try and pray for a better life. The characters in the story who try and pray generally become successful characters, while the characters who don't want to try become characters in the story who fail. 4) The story characters in life prioritize studying to do a job in life. 5) Stories describe characters who act quickly in dealing with and solving life's problems. 6) Story characters are full of calculations and deliberation in solving life problems. The actions that were carried out with full calculation and deliberation have resulted in an amazing solution from their life problems so that they become honorable and happy community leaders. 7) The ideal life is to live with knowledge, effort, and benefit for others. 8) A despicable life is a life of pleasure and no benefit and even trouble for others. 9) Story characters who have successfully contributed to family life in the form of prospering the family, increasing social status, and becoming leaders in society. 10) The success of the life of the characters in the story is related to the principles of life that are sourced from the Minangkabau traditional customs and teachings of Islam. That is, life is lived on the philosophical basis of customs and 
religion. 11) Life must be lived with trust, effort, and prayer in seeking knowledge and wealth for the sake of happiness in life in this world and in the hereafter [15].

The wisdom of educational culture in the nature of the work includes the following. 1) In general, story characters work as fillers in life and criticize story characters who spend their lives having fun without work. 2) The work is a place to get work that can improve social status, self-respect, and family welfare. 3) Some of the prominent works are migrating to trade and seeking knowledge in addition to other businesses. 4) The story describes the work that becomes the business of life and in general the story provides guidance on how to work for success in life. 5) Other works as teacher and author, painting and embroidery, sewing and weaving, trading, cooking. 6) A boy, six years old, is sent to school in the afternoon, taught at home in the evening, and sent to the "surau" at night. 7) Work is part of life's activities that are enjoyed to meet the needs of life and to provide benefits to family and others. 8) Work is to get out of poverty to become rich, to get out of ignorance to become a scholar, wise and wise, to get out of low social status to become a person with a position like being a leader (penghulu).

Cultural wisdom in the nature of time includes the following. 1) Generally wisdom about time, oriented to the future by making good use of the present time and taking lessons from past events. 2) It is described in the story implicitly that the character who fills time with useful activities will determine happiness in the future. 3 ) In the story, the use of the time of day and night is patterned in the form of traditional petatah-petitih originating from the Islamic religion. 4) Another adage regarding the use of time reads "Days are in thirds, nights are in quarters". The afternoon is divided into three, the first time is to fill one's passions, the second time to work and try, third, time to carry out family/people management. The time of night is divided by four, the first is the historical time and discussing it, the time to think about the rules, the time to consider the truth, the fourth time to remember Allah and the Messenger of Allah. Based on these findings, it can be stated that stories provide cultural messages so that readers use time effectively and think and act for the future by remembering the time in the past.

Cultural wisdom in the nature of the relationship with nature, including the following. 1) In general, the story describes the traditional instructions and examples of life based on the patterns and events that occur in nature or nature as a teacher. 2) The philosophy of life of the
Minangkabau ethnic group is famous for the adage "nature develops into a teacher", because of that in the story there are many stories related to nature as a teacher. 3) Recognition and knowledge of nature are preserved in petatah and rhymes as tools that become cultural symbols.

Cultural wisdom in the nature of relationships with others, including the following. 1) The description of peer relations is generally carried out by working together, agreeing with one another, and helping each other. 2) In carrying out the relationship between fellow characters in the story, they are led to pay attention to ethics and morals, therefore each party's characteristics are patterned in customary advice. 3) The prominent cultural messages related to relations with others are equality in expressing opinions, working together, helping each other, practicing ethical and moral values in customs, and reminding each other. 4) Stories contain many rules related to peer relations and stories function as educational tools in relations with others $[20.21,22,23,24,25,26,27,28,29]$.

\subsection{Message of Cultural Wisdom of Classical Stories for the Development of Literary Education}

Based on the message of cultural wisdom that has been explained in the previous subtopic, in this section several considerations are proposed based on the message of cultural wisdom for literary education innovation in general. These considerations are put forward with the principle of explaining the message of story culture wisdom in the form of statements in the form of statements in the hope that it will be developed in a literary education system that is needed by the community supporting story culture. If this wisdom is applied in the implementation of educational programs, it will certainly be an innovation that is relevant to people's expectations about literary education.

a. Based on the cultural message of the wisdom of the nature of life, the considerations for literary education innovation are as follows. First, the literary education expected by the people who support classical stories is an educational system whose vision is to educate students about the life of the world and the hereafter and with the mission of saving them from the life of this world to the life of the hereafter. Second, the character values that are highly expected as a result of education are knowledge, skills, effort, faith, worship, and piety in addition to other good characters. Third, to create educational outcomes with that character, educational materials must contain material on morals and culture, 
such as religious knowledge, skilled science, and cultural science (language) with a balanced and integrated portion. Fourth, the cultural community wants education graduates to be people who after graduation are not only workers but more than that they are able to lead with four pillars, namely knowledge, religion, culture, and business. Fifth, the profile of graduates who are expected to have the character of scientists, scholars, entrepreneurs, and culturalists.

b. Based on the cultural message of the wisdom of the nature of the work, the considerations for literary education innovation are as follows. First, education should train students to become people with character who love to work and create. Second, education is carried out with a place to work and evidence of educational success is shown by producing works/products (not only quantitative values from test results). Third, basic works are all skills for living alone and for married life taught in basic education. Fourth, monumental works related to skills and abilities to support the profession are taught at the top level of education. All graduates of primary and upper level education have the skills and skills to live.

c. Based on the cultural message of the wisdom of the nature of time, the considerations for literary education innovation are as follows. First, the education expected by the cultural community is one that makes students aware of the importance of time and fills it with useful activities. Second, education is expected to train students to use the present time for future happiness. Third, the educational process should provide training as far as possible how to live life by dividing the time that has been patterned by stories. Fourth, boarding education is a means to practice life using time according to the pattern of cultural messages (day and night).

d. Based on the cultural message of wisdom on the nature of the relationship with nature, the considerations for educational innovation are as follows. First, education is directed to a learning philosophy known as "nature develops into a teacher". Second, various behaviors and characteristics of nature, as well as the work of their body systems can be taken as patterns to build the development of knowledge and technology. Education is expected, namely those who can understand, realize, and maintain a relationship with nature, including the supernatural (?). Third, education should teach students how to explore nature, use nature, and preserve nature. Education should respect and care for nature and the preservation of nature is related to all fields of science.

e. Based on the cultural message of wisdom on the nature of relationships with others, the considerations for literary education innovation are as follows. First, literary education develops brotherly relations and equality without any element of domination, especially by the more powerful. Second, in social relations, all parties should show their best competence in knowledge, attitudes, and skills for good and progress and not in terms of material domination or personal goals. Third, piety is the basis for the formation of the character of helping each other (cooperating) with others. Education should make students aware of relationships that bring good and relationships that do not bring goodness and do not allow violence in any form. Classical folklore can be used as a tool to teach students so that they can find out how good peer relations are and in education are needed to form subtleties of taste.

\subsection{Implications of Story Culture Messages for Literary Education Innovation}

Based on the consideration of the cultural message described, several main things were put forward as implications for literary education innovations related to story culture wisdom.

\subsubsection{Learning folklore at school}

Valuable folk tales need to be mandatory reading in literary learning in schools in story-supporting communities, especially in primary and secondary education. The existence of stories as reading material in primary and secondary school education can contribute to the inheritance of the values of cultural education, language skills, and Minangkabau literature. The depletion of the practice of local culture in society cannot be allowed to just give in to the increasingly intimate relationship of the younger generation with global culture because the ownership of cultural values cannot be separated from the effort of cultural inheritance itself through education. Thus, reading stories and their appreciation at school can improve the quality of students who are not familiar with Minangkabau culture.

This is supported by the argument that the world in literary works is not a world of reality but is a fictitious and imaginative reality that the author seeks as a reflection of real life. Through literary works the author provides instructions and criticisms of real life. The 
author provides solutions to life problems experienced by the characters in the story as a comparison in real life. In the story, it can be found which culture is opposed and what things are justified in life, in work, in the use of time, in managing nature, and in dealing with others. The story rejects characters who are evil, bad-tempered, selfish, greedy, and unethical. On the other hand, the story justifies the character's behavior that is good, honest, hard working, humble, visionary, and useful in life. Therefore, the positive values are taken from the story and the negative values are discarded because the negative values are not in accordance with religion and customs. Thus, through learning at school about folklore, students will understand the demands of their culture.

\subsubsection{Translation of folk tales}

In order for the message of educational culture in the story to be widely understood by various groups, classic stories need to be translated into national and foreign languages. Foreign language learning in elementary, middle, and high schools can use translated folklore to learn. Thus, students master foreign languages with a touch of local and global culture. There is no other way, if you want students to be good at reading, read more and if you want students to be good at writing, write more. Students should be taught theory and hands-on practice [30].

\subsubsection{Applying educational innovation}

Educational managers need to take action with real programs to appreciate the values of cultural wisdom contained in classic stories both in education and in social life. Local governments need to fight for cultural values that are relevant to the cultural life of the people they lead. In this paper, it has been stated that the education expected by the community is that education provides a balance between the portion of teaching material between science and religion, a balance of knowledge and skills. The figure of a graduate who is expected to have a profile of scientists, scholars, businessmen, and cultural who are integrated in the vision of surviving in this world and surviving in the hereafter. The character of education graduates that are very necessary are faith, piety, knowledge, skills, and good culture.

\section{CONCLUSION}

Based on the description that has been submitted, it can be concluded as follows. First, literary education in national education must continue to be implemented as an effort to improve the system and quality of education. Although there are still many parties who are pessimistic about the formation of literary graduates with good culture, it is better if the implementation of education so far needs to consider cultural factors that are expected by the community. Second, innovations in literary education need to be considered by incorporating cultural wisdom that is a habit of people's lives which is reflected in their folklore. Third, the message of cultural wisdom that stands out in Minangkabau folklore about literary education is that life is lived with faith, worship and piety, knowledge and life skills. Life is lived by trying and praying and maximizing benefits for self, family and others.

The education needed by the community according to their folklore is education that forms the character of faith, worship, piety, knowledge, skills, and good culture. The implication is that cultural wisdom in stories about educational innovation is so that education provides teaching materials about religion, general knowledge and technology, life skills, and a balanced culture. Excavation of good community cultural wisdom needs to be actualized and then the education carried out will be innovated so that the mission is relevant to it. This study is only a consideration for educational innovation and needs to be discussed in relation to the theory of educational innovation. However, innovations in literary education based on the cultural wisdom of the people contained in folklore can have a good impact on the expected educational outcomes because graduates of cultured education are in accordance with the culture expected by society.

\section{REFERENCES}

1. Suyatno. (2009). Menjelajah Pembelajaran Inovatif. Sidoarjo: Masmedia Buana Pustaka.

2. Taufik, Iman. (2008). Jika Tidak Memiliki Daya saing Jadi Kuli di Negara Sendiri. Jakarta: Penerbit Papas Sinar Sinanti

3. Muslich, Masnur. (2011). pendidikan sastra Menjawab Tantangan Krisis Multidimensional. Jakarta: Penerbit Bumi Aksara.

4. Sofia, Y. A., \& Abdurahman, A. (2019, March). The Character Education Values in Literary Texts n Buku Siswa Bahasa Indonesia for Senior High School. In Seventh International Conference on Languages and Arts (ICLA 2018) (pp. 643-650) Atlantis Press. 
5. Sihotang, Steven, 2014. Probelamtik Pengajaran Sastra di Sekolah. https://www.jendelasastra.com/wawasan/artikel/pr oblematika-pengajaran-sastra-di-sekolah

6. Rivai, V. (2009). Education Management. Jakarta: PT RajaGrafindo Persada.

7. Shyrazy, H. (2015). Api Tauhid Cahaya Keagungan Cinta Sang Mujaddid. Jakarta:Republika Penerbit.

8. Terjemahan Al-Quran. Penerbit Zirul Hakin. 2012

9. Lickona, Thomas. 1991. Educating for Character: How Our School Can Teach Respect and Responsibility. New York: Bantam Books.

10. Kurikulum Baru 2021 https://www.yusufs.id/2020/12/kurikulum-baru2021-sd-smp-sma.html

11. Susanto Hery Pembaharuan Pendidikan Nasional. 2014. http://www.kompasiana.com/www.komunal.com/p embaruan-pendidikannasional_54f39dfb745513932b6c7c16

12. Sastromiharjo, Andojo. Perlunya Inovasi dalam Pembelajaran Bahasa dan Sastra. https://www.google.com/search?q=Inovasi+pendid ikan+sastra\&safe

13. Abdurahman, A. Nilai-nilai budaya dalam kaba minangkabau.suatu interpretasi semiotik. Padang: UNP Press. 2011.

14. Samovar, L. A. dan Richard E. Porter. 2001. Communication between Cultures. Belmont CA: Wadsworth Publishing Company.

15. Abdurahman. (2013). Pesan Kearifan Budaya dalam Kaba Minangkabau: Kajian Semiotik. Padang: Universitas Negeri Padang.

16. Sudikan, Setya Yuwana. Metode Penelitian Budaya. Surabaya: Citra Wacana. 2001.

17. Saifuddin, Achmad Fedyani. Antropologi Kotemporer. Jakarta: Kencana. 2006.

18. KBBI Daring. https://kbbi.kemdikbud.go.id/entri/KEARIFAN

19. Rahyono, FX. Kearifan dalam Kata. Jakarta:Wedatama. 2009
20. Endah, Sjamsuddin Sutan Radjo. (2008) Kaba Cindua Mato. Bukittinggi: Penerbit Kristal Multimedia.

21. Yakub, Dt. B. N. (1982). Kaba Tapian Larangan. Jakarta: Departemen Pendidikan dan Kebudayaan, Proyek Penerbitan Buku Sastra Indonesia dan Daerah.

22. Pangaduan, Sutan. (2008). Kaba Magek Manandin. Bukittingi: Penerbit Kristal Multimedia.

23. Manggis, M. Rasyid. (2004). Kaba Sabai nan Aluih Bukittinggi: Penerbit Kristal Multimedia.

24. Alam, Dt. Panduko. (2004). Kaba Rancak Di Labuah. Bukittinggi: Kristal Multimedia.

25. Basa, Bahar Datuak Nagari. (1982). Kaba Sutan Lanjungan. Jakarta: Balai Pustaka.

26. Bakar, Jamil. (1979). Kaba Lareh Situjuah dalam Kaba Minangkabau. Jakarta: Pusat Pembinaan dan Pengembangan Bahasa.

27. Bakar, Jamil. (1979). Kaba Bujang Pajudi dalam Kaba Minangkabau 2. Jakarta: Pusat Pembinaan dan Pengembangan Bahasa.

28. Endah, Sjamsuddin Sutan Radjo. (2004a) Kaba Si Buyuang Karuik. Bukitinggi: Penerbit Kristal Multimedia.

29. Endah, Sjamsuddin Sutan Radjo.(2004b). Kaba Siti Baheram. Bukittinggi: Penerbit Kristal Multimedia.

30. Emzir \& Rohman Saifur. Teori dan Pengajaran Sastra. Jakarta: RajaGrafindo Persada. 2015. 